Article

\title{
Social Representations of Flooding of Future Teachers of Primary Education (Social Sciences): A Geographical Approach in the Spanish Mediterranean Region
}

\author{
Álvaro-Francisco Morote ${ }^{1, *(1)}$ and María Hernández ${ }^{2}$ (1) \\ 1 Department of Experimental and Social Sciences Education, Faculty of Teaching Treaning, University of \\ Valencia, 46022 Valencia, Spain \\ 2 Regional Geographic Analysis and Physical Geography Department, University of Alicante, \\ 03690 Alicante, Spain; maria.hernandez@ua.es \\ * Correspondence: alvaro.morote@uv.es
}

Received: 15 June 2020; Accepted: 26 July 2020; Published: 28 July 2020

check for updates

\begin{abstract}
The risk of flooding is the main natural hazard that affects the European Mediterranean region. This hazard has worsened in recent decades due to the occupation of flood areas and the effects of climate change. Therefore, understanding and gaining a more in-depth knowledge of social representations of flooding is important. In addition, interest in this subject is accentuated in the case of future teachers. This is because it is mandatory to teach this subject in Primary Education (Grades 1-6; Social Sciences subject). The aims of this research are: (1) To explore the instruction about flooding received by future teachers during their school period, and (2) to examine their perception about factors influencing flood risk. Methodologically, a questionnaire was distributed among future teachers of Primary Education (Faculty of Teaching Training, University of Valencia, Spain). The results regarding the respondents' perception show that only $21.3 \%$ of the future teachers received instruction about floods during their school period. With reference to factors that influence floods, they mostly believe that the main factors are climate change and the spatial land management. Furthermore, $51.3 \%$ believe that this phenomenon has been increasing over the last few years, and $82.5 \%$ think that it rains heavier today.
\end{abstract}

Keywords: floods; instruction; geography

\section{Introduction}

Natural hazards, specifically those of an atmospheric nature, are generating an increasing volume of economic and human losses [1]. On a global scale, according to the report published by the Center for Research on the Epidemiology of Disasters (CRED) [2], floods are the most frequent natural hazard (with a percentage of $43 \%$ of the total) and affected the most people (two billion inhabitants) between 1998 and 2017 in the world. With respect to flood deaths, these amounted to 142,088 (11\% of the total victims of natural disasters). In Europe, the report published by the European Environmental Agency [3] highlighted that between 2000 and 2014, there were approximately 2000 deaths and almost 8.7 million people affected by floods. To this should also be added that the effects of climate change, such as heavy rainfall, are predicted to become more frequent and intense, according to different international [4] and Spanish reports [5].

Spain is one of the European countries with the highest levels of flood risk [6]. According to the Atlas of the Human Planet [7], the population exposed to this risk increased by $24 \%$ between 1975 and 2015 [7]. According to Olcina [8], in Spain, two million people live in areas at high risk of 
flooding, and during the period 1995-2015, a total of 526 deaths were recorded due to this phenomenon. The areas with the highest risk are located in coastal areas, especially the Mediterranean coast (study area). These are called "flood risk regions" due to the high frequency of events and the large economic and human life losses [9]. In the Region of Valencia (study area), according to the Action Plan of the Territorial Action for Flood Risk Prevention, approximately 600,000 inhabitants (12\% of the population) live in flooded areas [10].

Natural risk management has undergone significant changes over the last two decades in developed countries [7]. Currently, the main lines of action to reduce risk are environmental issues and a more effective spatial land management [9]. In previous decades, the main measure to reduce flood risk was the construction of hydraulic works to guarantee the necessary level of security in the affected areas [11]. These actions led to overconfidence in the engineering works and the maintenance and development of inappropriate actions that increased exposure and vulnerability. Since 2000, actions aimed at decreasing hazards have given way to measures to reduce vulnerability and exposure. These are based on land management uses, risk mapping, and the construction of "soft" infrastructures that are more respectful with the environment [12]. However, instruction from educational centers (a non-structural action) is largely overlooked [13]. In developed countries, it is considered essential to train future citizens in issues related to science. To do this, teaching is probably the most effective tool to improve their knowledge, not only in the scientific field, but also with respect to everyday life [14].

The Social Sciences—and, more specifically, Geography—could contribute to increasing knowledge on flood risk [15]. Geography contributes the spatial dimension to knowledge in education, facilitating the understanding of information, concepts, procedures, and attitudes with respect to the location and distribution of different events in a space [14]. In Spain, in the case of Primary Education (1st to 6th Grade; from 7 to 12 years of age), geographic contents are taught in the subject of Social Sciences, enabling children to acquire skills with which to analyze the occupation of space by society and to critically assess the territory resulting from this transformation [15]. This instruction seeks to improve the students' understanding of the local area and to modify their aspirations and conduct so as to foster sustainable local development [16].

Different studies over the last decade highlight the importance given to the study of flooding at all educational levels; for example, in the United States, [17,18], United Kingdom [19], Poland [20], Slovenia [21], Romania [22], or Asia [23]. The majority of the scientific studies on flooding from an education perspective have been carried out through the Experimental and Natural Sciences [24,25]. In Spain, these types of works related to teaching of Geography and/or Social Sciences are uncommon $[26,27]$. However, in the Region of Valencia, except for a few recent studies [15,28-30], publications on this issue are scarce.

When analyzing the risk of flooding from an education perspective, the incidence of climate change should not be forgotten. As indicated by different studies carried out by the Geographical Association (United Kingdom), over the last ten years, the Primary Education teaching programs in the English-speaking world have been incorporating the risks of flooding [31] and climate change [32]. They consist of educational proposals in which the vulnerability factor is an important aspect. In other words, they take into account how human beings have settled and increased the risk due to the occupation of flood hazard areas. Along these lines, a report published by the European Environmental Agency stresses the need to place greater importance on this factor (vulnerability) given its relevance for addressing the adaptation to climate change and the foreseeable increase in flooding episodes [3].

The research problem addressed in this study is that the risk of flooding is a relevant topic on a social, economic, and territorial level in Spain. Therefore, it should be studied by Primary Education students in order to contribute to the understanding of this phenomenon. The inclusion of so-called "socio-environmental" problems is relevant in Social Sciences programs [13]. However, due probably to the lack of training and knowledge of the current and future teachers in this subject, its transmission to the youngest cohorts can be unclear [13]. Therefore, teachers need to be trained in this subject area. 
The interest of this research is based on the following questions: (1) in Spain, the risk of flooding is the most important natural hazard that affects the country, particularly in the Mediterranean area; (2) the Region of Valencia (study area) has become a "risk region" due to both its climate characteristics and its territorial model (occupation and urbanization of floodable areas) [33]; (3) according to the future scenarios of climate change, the risk of flooding will become more frequent and intense [4]; (4) there is a lack of research on Geography instruction that addresses the risk of flooding, both in the study area (Mediterranean region) and on a national level; (5) the relevance of the education factor as a non-structural measure for reducing risk has traditionally been overlooked; and (6) this topic should be addressed in Primary Education (in Block 2 of the Social Sciences subject that is related with Geography) as established in the current educational curriculum for the Region of Valencia (Decree 108/2014 of 4 July) and on a national level (Royal Decree 126/2014 of 28 February).

The aims of this research are: (1) to explore the instruction on flooding of future teachers during their school period, and (2) to examine their perception about the factors that influence the flood risk. The hypothesis of this study is that the majority of the future Primary Education teachers who have taken part in this research did not receive any training on this subject during their school years. Second, in the case of respondents who did receive training, it is thought that they should give greater importance to the education factor as a variable that may affect the flood risk. Third, these trainee teachers have the perception that the risk of flooding has worsened in recent years due to climate change (increase in hazard) and not due to human factors (for example, the occupation of risk areas).

\section{Methods}

\subsection{Design of the Research}

This research is based on a mixed correlational and exploratory study (non-experimental). It takes a transversal design, as the information analyzed was gathered at a specific moment (the academic year of 2019-2020) and as a case study (students of the Faculty of Teaching Training of the University of Valencia, Spain).

\subsection{Context and Respondents}

In relation to the context and the respondents, the selection procedure was conducted through non-probability sampling (availability or convenience sampling). Two groups from the 4th year of the Primary Education Teacher degree from the Faculty of Teaching Training (University of Valencia) were selected. All participants attended the subject of "Didactics of Social Sciences. Applied Aspects" (code 33651; academic year 2019-2020). This is a theoretical-practical subject that contains geographic content; in fact, it is one of the few subjects where geographic content is taught in the Primary Education degree. With respect to the representativeness of the sample, taking into account the total number of students enrolled (96 students), in order to achieve a confidence interval of $95 \%$ and a margin of error of $5 \%$, a minimum of 77 students would be required to constitute a representative sample. The final total number of respondents was 80 , so a representative number was achieved.

With respect to the socio-cultural characteristics, it should be noted that the majority of the respondents were women $(67.0 \%)$. These data are within the normal ranges of the type of student of the Faculty of the Teaching Training, as the percentage of women in the final year is $70.2 \%$ [34]. With regard to age, the range of the sample is mainly between 21 and 25 years of age (97.5\%).

\subsection{Questionnaire, Data Analysis, and Procedure}

The instrument designed to carry out the research consisted of a questionnaire in order to obtain the information necessary to meet the objectives proposed. The questionnaire was divided into six sections with a total of 19 items: (1) social characteristics; (2) the flood risk in your village; (3) flooding events in the school (Primary Education) - the route from home to school; (4) training on the flood risk in school years; (5) the perception of the flood risk assertion; and (6) teacher training on flood risk in 
Primary Education. For this study (according to the aims proposed), the results obtained from parts 4 and 5 were used (see Table 1 ).

Table 1. Items of the questionnaire used for this research.

\begin{tabular}{|c|c|}
\hline \multicolumn{2}{|c|}{ Part 4. Training on Flood Risk in School Years } \\
\hline Item $\left(n^{\circ}\right)$ & Response Type/Variables \\
\hline $\begin{array}{l}\text { Item } 11 \text {. During your school years, did you receive } \\
\text { any type of information about flood risk? Could you } \\
\text { indicate the information that you received? }\end{array}$ & $\begin{array}{l}\text { Closed-ended question: Yes/No/Do not know/No answer (in } \\
\text { the case of an affirmative response, please briefly explain the } \\
\text { information received). }\end{array}$ \\
\hline $\begin{array}{l}\text { Item } 12 \text {. If the previous response was affirmative, } \\
\text { in which stages of your education do you remember } \\
\text { receiving this information? }\end{array}$ & $\begin{array}{l}\text { Closed-ended question: Primary Education/Secondary } \\
\text { Education/Baccalaureate }\end{array}$ \\
\hline \multicolumn{2}{|c|}{ Part 5. The Perception of Flood Risk Management } \\
\hline Item $\left(n^{\circ}\right)$ & Response Type/Variables \\
\hline $\begin{array}{l}\text { Item } 13 \text {. Are there more events of floods now than } \\
\text { when you were at school? }\end{array}$ & $\begin{array}{l}\text { Closed-ended question: Yes/No/Do not know/No answer } \\
\text { (place was left to explain the respondents' opinions). }\end{array}$ \\
\hline $\begin{array}{l}\text { Item 14. In your opinion, how important are the } \\
\text { following factors in flood risk? }\end{array}$ & $\begin{array}{l}\text { Likert scale. Value: } 1 \text { to } 5 \text {, with } 5 \text { being the highest value and } 1 \\
\text { the lowest: Spatial land management/Loss of culture of the } \\
\text { territory by society/Climate change/Preventive and emergency } \\
\text { measures/Teaching in schools/Negligence by human beings } \\
\text { (risk perception " } 0 \text { "). }\end{array}$ \\
\hline $\begin{array}{l}\text { Item } 15 . \text { Has the way in which it rains changed } \\
\text { compared to a few decades ago? }\end{array}$ & $\begin{array}{l}\text { Closed-ended question: It rains more and more intensely/It } \\
\text { rains more and less intensely/It rains more but with the same } \\
\text { intensity/It rains the same but with greater intensity/It rains the } \\
\text { same but with less intensity/The way it rains has not changed } \\
\text { (in frequency or intensity)/It rains less but with greater } \\
\text { intensity/It rains less and with less intensity/It rains less (but } \\
\text { the intensity has not changed)/Do not know/No answer. }\end{array}$ \\
\hline
\end{tabular}

With reference to data analysis, when necessary, non-parametric statistics were used to contrast hypotheses. Mann-Whitney and Wilcoxon's tests were considered suitable for non-normalized distributions to establish relations between the items 11 and 14. Table 2 shows the coding that has been used to organize the results of items 13,14, and 15.

Table 2. Coding for interpretation and analysis of results.

\begin{tabular}{lc}
\hline \multicolumn{1}{c}{ Coding of Item 13 (Reasons Given by Respondents) } \\
Due to climatic change & CC \\
Due to recklessness/action/inaction of human beings & HU \\
Due to lack of training and prevention/security measures & ED+ \\
There are more training/education/security measures & ED- \\
Infrastructure improvements & BA- \\
Due to architectural barriers/buildings in flood-prone areas & BA+ \\
Decline and neglect of rural landscape & AG \\
\hline \multicolumn{1}{c}{ Coding of Item $\mathbf{1 4}$ (Importance of Factors Influencing Flood Risk) } \\
Spatial land management & SpMan_Imp \\
Culture of the territory & TeCul_Imp \\
Climatic change & CC_Imp \\
Preventive measures & PreMe_Imp \\
Education (training) & Edu_Imp \\
Risk perception “0” & RisZero_Imp \\
\hline
\end{tabular}

Source: Own elaboration.

The questionnaire was distributed in an intermediate session (first four-month period) during the last week of November (2019) and with a response time of $20 \mathrm{~min}$. The questionnaire was also validated by two researchers from the Department of Experimental and Social Sciences Education at the 
University of Valencia (Spain) and a researcher from the Department of Regional Geographic Analysis and Physical Geography of the University of Alicante (Spain). All the respondents answered all the questions; the participants' anonymity was preserved during the entire procedure and confidentiality was guaranteed in writing.

\section{Results}

\subsection{Training on the Risks of Flooding in School Years}

With respect to training during their school years (item 11$)$, only $21.3 \%(n=17)$ of the future teachers remember having received information on this topic (Table 3). Furthermore, the majority of those who responded affirmatively highlighted that this information had been very basic and had been drawn from: textbooks, action protocols issued by the police or emergency services (fire fighters), or based on explanations by the teacher regarding certain past episodes and the relationship of these phenomena with the Mediterranean climate (the so-called "gota fría"—cold drop) (Table 4).

Table 3. Item 11: "During your school years, did you receive any particular information about the flood risk?".

\begin{tabular}{ccc}
\hline & Frequency (n) & Percentage (\%) \\
\hline Yes & 17 & 21.3 \\
No & 55 & 68.8 \\
Do not know/No answer & 8 & 10.0 \\
Total & $\mathbf{8 0}$ & $\mathbf{1 0 0}$ \\
\hline
\end{tabular}

Source: Survey results. Own elaboration.

With respect to item 12, the respondents had to identify in which stage of their schooling they recalled having received the information about these phenomena (those who responded affirmatively to item 11). The results highlighted that the majority remember having received this information in Secondary Education (39.3\%; $n=13)$, followed by Primary Education $(21.2 \% ; n=7)$, and finally in Baccalaureate $(15.1 \% ; n=5)$. A possible explanation for these results may be due to two reasons: $(1)$ in Spain, in the Baccalaureate (stage prior to the university), the subject of Geography is optional; (2) the subject is focused on the University Entrance Exams (UEE), and is thus focused more on how to pass the exam than on the teaching-specific contents such as flood risk.

\subsection{Is the Flood Risk Increasing? Perception of the Possible Factors According to Future Primary Education Teachers}

In this part of the questionnaire, the questions are aimed at analyzing the perception that future Primary Education teachers have of flood risk, specifically: (1) the perception of whether more floods events are happening today than when they went to school (item 13); (2) the importance of the factors contributing to them (item 14); and (3) the perception of whether the way it rains has changed in terms of quantity and intensity (item 15).

The responses to the first question (item 13) show that $51.3 \%(n=41)$ believe that now there are more floods, while for $30.0 \%(n=24)$, the response was negative. Another meaningful result is the number of respondents who indicated that they were unaware of the trend of these episodes $(18.8 \% ; n=15)-$ a number of responses almost identical to that of the previous answer. It is worth highlighting that the large majority of those who gave an affirmative answer related it to climate change $(47.5 \%$; $n=38)$ (see Table 5): "when I went to school, there were never floods in the Valencian territory", "it rains more now", "the rains are heavier now", "these phenomena are happening more frequently due to climate change", etc. On the other hand, the second most frequent response (although a minority) explained that the main cause of the increase in the risk of flooding is not so closely related to the increase in the episodes of rain. It is the construction of infrastructures that have changed the 
runoff or the occupation of flood-prone zones and the negligence of human beings: "because buildings are often constructed with no regard to safety and risk prevention", "the floods also happen due to a lack of information and prevention by citizens", "because prevention measures are not taken, negligence of human beings", etc. In other words, these responses refer to the increase in vulnerability. With reference to the education factor, it only represents $11.2 \%$ of the responses $(n=9)$. These data show that this factor (training of young people) is not considered as a variable that can influence vulnerability to the risk of flooding. This result is most worrying, as the respondents of this research will be teachers in the future.

Table 4. Classification of the responses of the future teachers who confirmed having received training on flood risk during their school years (item 11).

\begin{tabular}{cl}
\hline Source of the Explanations of Flood Risk & \multicolumn{1}{c}{ Responses } \\
Textbooks & "The information in the textbooks" \\
- "I learned about floods in subjects such as Social Sciences, \\
"- "Ont only what was in the books"
\end{tabular}

Source: Survey results. Own elaboration.

Table 5. Reasons for the answers given by the respondents in item 13.

\begin{tabular}{ccc}
\hline Reasons & $\begin{array}{c}\text { Frequency } \\
\text { (n) }\end{array}$ & $\mathbf{\%}$ \\
\hline AG & 1 & 1.2 \\
BA- & 1 & 1.2 \\
BA+ & 5 & 6.2 \\
CC & 38 & 47.5 \\
ED- & 6 & 7.5 \\
ED+ & 3 & 3.7 \\
HU & 4 & 5 \\
Nothing & 29 & 36.2 \\
Total & $\mathbf{8 7}$ & $\mathbf{1 0 0}$ \\
\hline
\end{tabular}

Source: Survey results. Own elaboration.

With respect to item 14, the results reinforce the data and opinions observed in the previous question. The results obtained, in order of importance, highlight that in the increase of risk, the most 
important factors are climate change and the territorial culture (understood as how society has managed the use of the land; for example, urbanization of flood-prone areas, occupation of watercourses, etc.). These two issues have an average score of 4.5 (Table 6). In third place are "prevention measures", that is, the authorities' failure to implement prevention measures when managing these events. Significantly, the "education" factor has the penultimate position (3.6). This variable is related to citizens' training from school age, that is, a society educated in the risk of flooding will enable itself to be less vulnerable to these phenomena. Table 6 shows the overlap of the respondents' reasoning in item 13 with the value they give to the factors that influence floods (item 14). The results highlight that there is some coherence between the reasons and importance given to the proposed factors.

Table 6. Relationship between the importance of the factors that influence flood risk (item 14) and the reasons given for the frequency of these events (item 13).

\begin{tabular}{|c|c|c|c|c|c|c|c|}
\hline Reasons & & SpMan_Imp & TeCul_Imp & CC_Imp & PreMe_Imp & Edu_Imp & RisZero_Imp \\
\hline \multirow[t]{2}{*}{ Nothing } & Average & 4.7 & 3.1 & 4.8 & 4.4 & 3.8 & 4.1 \\
\hline & $\mathrm{N}$ & 29 & 29 & 29 & 29 & 29 & 29 \\
\hline \multirow[t]{2}{*}{ BA- } & Average & 4 & 5 & 5 & 5 & 4 & 4 \\
\hline & $\mathrm{N}$ & 1 & 1 & 1 & 1 & 1 & 1 \\
\hline \multirow[t]{2}{*}{ BA+ } & Average & 5 & 2.8 & 4.4 & 4.2 & 2.4 & 4.6 \\
\hline & $\mathrm{N}$ & 5 & 5 & 5 & 5 & 5 & 5 \\
\hline \multirow[t]{2}{*}{$\mathrm{CC}$} & Average & 4.2 & 3.1 & 4.3 & 4.4 & 3.4 & 4.0 \\
\hline & $\mathrm{N}$ & 38 & 38 & 38 & 38 & 38 & 38 \\
\hline \multirow[t]{2}{*}{ ED- } & Average & 4.7 & 2.7 & 4.3 & 4.8 & 4.0 & 4.3 \\
\hline & $\mathrm{N}$ & 6 & 6 & 6 & 6 & 6 & 6 \\
\hline \multirow[t]{2}{*}{ ED+ } & Average & 4.3 & 3.3 & 4.7 & 4.7 & 4.7 & 4.7 \\
\hline & $\mathrm{N}$ & 3 & 3 & 3 & 3 & 3 & 3 \\
\hline \multirow[t]{2}{*}{ HU } & Average & 4.5 & 3.5 & 4.7 & 4.5 & 4.5 & 4.5 \\
\hline & $\mathrm{N}$ & 4 & 4 & 4 & 4 & 4 & 4 \\
\hline \multirow[t]{2}{*}{ AG } & Average & 5 & 5 & 5 & 1 & 1 & 5 \\
\hline & $\mathrm{N}$ & 1 & 1 & 1 & 1 & 1 & 1 \\
\hline \multirow[t]{2}{*}{ Global } & Average & 4.5 & 3.1 & 4.5 & 4.4 & 3.6 & 4.2 \\
\hline & $\mathrm{n}=$ & 87 & 87 & 87 & 87 & 87 & 87 \\
\hline
\end{tabular}

Source: Results of the questionnaire. Own elaboration.

In the last item of this section (item 15), the respondents were asked whether the way in which it rained had changed (Table 7). The results show that half of the respondents $(50.0 \% ; n=40)$ think that it now rains less (in amount) but with a greater intensity. In second place are the responses of those who think that it now rains more and with a greater intensity $(30.0 \% ; n=24)$. In third place, but with a much lower number of responses, are the opinions of those participants who answered that they did not know or did not answer $(8.7 \% ; \mathrm{n}=7)$. These data indicate that the future teachers believe that it rains more intensely today $(82.5 \%)$. These responses partly match with the forecasts indicated by the different reports on climate change that forecast greater irregularity for the Mediterranean area-specifically, a reduction in the days of rain and a greater intensity [4].

Table 7. Item 15:“Has the way in which it rains changed compared to a few decades ago?

\begin{tabular}{cccccccc}
\hline \multirow{2}{*}{ Quantity } & \multicolumn{9}{c}{ Intensity } & \multirow{2}{*}{ Total } & \multirow{2}{*}{ \% } \\
\cline { 2 - 7 } & More & Same & Less & Do Not Know/No Answer & \\
\hline More & 24 & 4 & 0 & 0 & 28 & 35.0 \\
Same & 2 & 0 & 0 & 0 & 2 & 2.5 \\
Less & 40 & 3 & 0 & 0 & 43 & 53.7 \\
Do not know/No answer & 0 & 0 & 0 & 7 & 7 & 8.7 \\
Total & $\mathbf{6 6}$ & $\mathbf{7}$ & $\mathbf{0}$ & $\mathbf{7}$ & $\mathbf{8 0}$ & $\mathbf{1 0 0}$ \\
$\%$ & $\mathbf{8 2 . 5}$ & $\mathbf{8 . 7}$ & $\mathbf{0}$ & $\mathbf{8 . 7}$ & $\mathbf{1 0 0}$ & \\
\hline
\end{tabular}

Source: Survey results. Own elaboration. 
When analyzing the relationship between training (item 11) and the factors that influence flood risk (item 14), the results show that future teachers with previous education on flooding and future teachers without prior education did not significantly differ (Mann-Whitney test: $U=515.5 ; p>0.05$ ). Only significant differences appear in the importance of the factor "prevention measures", where those who did receive training give more importance than the rest. In the case of the factor "education", there are no significant differences (Table 8). As for the respondents who report having received training at the school stage, interestingly, they value the "prevention measures" and "climate change" more. However, they give lower scores to the factor's "education" and "culture of the territory" (Table 9). The score for "education factor" is only 2.7. Pairwise comparisons between the education factor and all other variables show that there are only significant differences between the education factor and "prevention measures" (Wilcoxon test: $p=0.018$ ) as well as "climate change" (Wilcoxon test: $p=0.005)$. In this regard, both those who did not receive training and those who answered that they do not agree gave the education factor a higher score than those who did receive training (3.6 and 3.5 in both cases) (Table 10).

Table 8. Relationship between the training received (item 11) with the factors that influence the risk of flooding (item 14).

\begin{tabular}{ccccccc}
\hline & SpMan_Imp & TeCul_Imp & CC_Imp & PreMe_Imp & Edu_Imp & RisZero_Imp \\
\hline U of & 467.5 & 416.5 & 482.5 & 349.5 & 515.5 & 529.5 \\
Mann-Whitney & -0.947 & -1.433 & -0.756 & -2.644 & -0.244 & -0.076 \\
$\begin{array}{c}\text { Z } \\
\text { Sig. asymptotic } \\
\text { (bilateral) }\end{array}$ & 0.344 & 0.152 & 0.45 & 0.008 & 0.807 & 0.939 \\
\hline
\end{tabular}

Source: Own elaboration.

Table 9. Relationship between the participants who did receive training (item 11) and the factors that influence the risk of flooding (item 14).

\begin{tabular}{cc}
\hline \multicolumn{2}{c}{ Range } \\
\hline \multicolumn{2}{c}{ Average Range } \\
\hline SpMan_Imp & 3.5 \\
\hline TeCul_Imp & 2.7 \\
\hline CC_Imp & 4.0 \\
\hline PreMe_Imp & 4.6 \\
\hline Edu_Imp & 2.7 \\
\hline RisZero_Imp & 3.1 \\
\hline \multicolumn{2}{c}{ Friedman test } \\
\hline N & 17 \\
\hline Chi-cuadrado & 21.667 \\
\hline gl & 5 \\
\hline Sig. asymptotic & 0.001 \\
\hline Source: Results of the questionnaire. Own elaboration
\end{tabular}


Table 10. Relationship of the respondents who did not receive training and those who do not agree (item 11) with the factors that influence the risk of flooding (item 14).

\begin{tabular}{cccc}
\hline $\begin{array}{c}\text { Middle Ranges } \\
\text { (Respondents Who did not Receive Training) }\end{array}$ & \multicolumn{2}{c}{$\begin{array}{c}\text { Middle Ranges } \\
\text { (Respondents Who do not Remember) }\end{array}$} \\
\hline \multicolumn{2}{c}{ Average Range } & \multicolumn{2}{c}{ Average Range } \\
\hline SpMan_Imp & 4.4 & SpMan_Imp & 4.6 \\
TeCul_Imp & 2.9 & TeCul_Imp & 3.0 \\
CC_Imp & 4.5 & CC_Imp & 4.1 \\
PreMe_Imp & 4.3 & PreMe_Imp & 4.1 \\
Edu_Imp & 3.6 & Edu_Imp & 3.5 \\
RisZero_Imp & 4.0 & RisZero_Imp & 4.2 \\
\hline
\end{tabular}

Source: Results of the questionnaire. Own elaboration.

\section{Discussion}

This study carried out a first analysis of the perception that future Primary Education teachers have of the risk of flooding (in a case study of the University of Valencia, Spain). With regard to their recollection of these contents during their school years, particularly noteworthy is the low value obtained; only $21.3 \%$ responded affirmatively. The first of the hypotheses is fulfilled. However, it should also be noted that the respondents indicate that the instruction received was brief, superficial, and based on information drawn from textbooks, emergency protocols, or the explanation of the "gota fría" phenomenon. Therefore, their responses reveal the incapacity and scarce training in these issues of the teaching staff, as they principally resorted to school manuals or experts in the field (protocols) to explain it. This could be one reason for why the second hypothesis is not fulfilled. That is, the poor training received may have influenced these students to believe that the information is not meaningful and adequate to deal with in classrooms. On the other hand, it seems that those who did not receive training or who do not remember consider it to be an issue to be dealt with due to its relevance in daily life. However, in any case, it is still one of the least valued factors.

Morote and Souto [35] obtained similar results for the Mediterranean region, where only $12.1 \%$ of the future Primary Education teachers received information during their school period. School textbooks are not the best option due to the errors and stereotypes usually found in them, as pointed out by Souto et al. [30] in the case of flooding and Morote [13] for climate change. The former indicated that in order to explain flooding, the classic Cycle of Erosion by Davis-dating to the nineteenth century-is still being used and has become an obsolete explanation. This reveals that very few refer to the effect of anthropogenic action on the natural flow regime of rivers, and the information on the concept of hazards (both in contents and proposed activities) is practically non-existent. Morote [13] states that in Spain, in terms of climate change, in the Social Sciences textbooks (Primary Education), the contents are full of mistakes. These mistakes are replicated in the media (Internet, TV, and social networks), creating a catastrophic image that is not justified by climate change, accompanied by images and photographs that are completely unrelated to this phenomenon. Furthermore, this author explains that human beings (the vulnerability factor) are practically inconspicuous due to their absence from these school textbooks. These shortcomings were also noted by Abbot et al. [36], who, after selecting 450 diagrams of the water cycle in textbooks, scientific publications, and the Internet, reached the conclusion that around $85 \%$ do not refer to human interaction with the natural processes. This fact has also been highlighted in studies carried out in the United States by Lutz [17]. This author highlighted that an analysis of physical geology textbooks used in introductory courses shows that there is a systematic lack of clarity regarding flood risk. This fact was also observed in this research, which took the future teachers' opinions into account. In other words, there is a significant lack of any mention of human beings when explaining flooding events.

With respect to the emergency protocols, this paper corroborates what Ramiro [37] found in the 1990s—namely, the need to address this problem with the help of experts, as the teachers' subjectivity 
could undermine the school's objective because they do not have precise knowledge of the hydrographic system. This finding was also obtained by Souto et al. [30] for the Spanish Mediterranean region, that is, the lack of initiative and training of future teachers when addressing these issues in Social Science classes at the Primary Education level. As a positive factor, although a minor element, it is worth mentioning the responses related to the explanation of the atmospheric phenomenon of the "gota fría", the atmospheric process that can give rise to heavy rain episodes in the Mediterranean region. The factors for this situation to occur are explained: (1) cold air at height; (2) coincidence with the time of the year when the Mediterranean Sea has a higher temperature (late summer months), (3) easterly winds, and (4) particular land morphologies, such as mountainous systems perpendicular to the direction of the wet maritime winds.

Regarding the third hypothesis, this was fulfilled. The climate change factor is considered one of the variables that most influences flood risks. In the analysis of the factors that explain the assertion of the risk of flooding, Morote [15] states that $64.5 \%$ of students studying to become Primary Education teachers believe that climate change has a direct influence on the aggravation of flood risk. The responses of respondents who believe that climate change has "little" or "very little" influence $(31.1 \%)$ are illustrative. These respondents believe that the floods are due more to (1) deficient urban planning and the occupation of flood hazard areas, and (2) issues relating to the absence of riverbank cleaning. These statements ratify those obtained in this study, which corroborates that a small percentage of future teachers consider that heavy rain events are not becoming more frequent, but the vulnerability risk is increasing (a higher exposure of society, occupation of floodable areas, etc.) (item 13).

In light of the results obtained, addressing this issue in Primary Education is vitally important, as it is necessary to teach how this phenomenon works to the youngest cohorts. However, this explanation should be simple so that the students are able to understand it easily. In other words, it should be carried out through didactic transposition or "transforming wisdom into learned knowledge", as knowledge undergoes transformations to be taught in classrooms [38]. To do this, Souto et al. [30] propose activities based on (1) how to act in a flood episode, (2) an analysis of past episodes, and (3) field trips as a resource for analyzing the risk in situ, and thereby achieving a better understanding of the territory. Based on their experience with a field trip on flood risk, Morote and Pérez [29] reveal that the benefits generated for the students are immediate and, in the long term, undeniable. This type of training activity creates awareness among the learners and fits them with the capacity to act in contingency situations that they did not have before due to a lack of perception.

With reference to new methodological proposals and instruction resources, Lutz [17] proposed an alternative conception of risk based on the analogy between playing a game of chance and living in a hazardous situation. In this way, statistical ensembles are introduced as a means to characterize risk as a function of the exposure duration by flood risk management professionals in local governments. This author considered that roleplaying about processes and structures enables an evaluation to be made of participants' perceptions of their learning experiences. The importance of awareness among learners about the causes and pattern of disasters, pre- and post-disaster management strategies, and preparedness for the proneness for contemporary global disaster was analyzed by Ahmad and Numan [23] in a study in Bangladesh. These authors insist that the lack of awareness of the sustainable use of natural resources and the consequences of the heedless consumption by the inhabitants has enhanced the degree and frequency of these natural disasters in recent decades.

Understanding the social representations that future teachers have of flooding constitutes a priority action for generating changes in their behavior and, therefore, that of their future students. In Spain, studies have been carried out on social representations and climate change, such as that of Arto [39], which studies students in Primary and Secondary Education. Based on drawings in which they had to summarize what they understood of climate change, the principal responses were related to negative sensations and thoughts (19.5\%) and an increase in temperatures (18.0\%). In Latin America, we can refer to the study carried out in Mexico by González and Maldonado [40], who, based on the 
analysis of social representations in university students, highlighted that the scientific information transmitted by different sources (scientific and mainstream) is sufficiently influential among young people so as to generate changes in behavior to slow climate change. These authors conclude that new communication and environmental education strategies should be implemented that are designed to generate pro-environmental conducts in the learners. With respect to the sources of information and how they condition the perception of future teachers, Morote et al. [41] reveal that the majority receive information about climate change through broadcast media and the Internet $(86.2 \%)$, as opposed to $5.3 \%$ who learn about it through the academic world.

Therefore, it is necessary to address the phenomenon of flood risk in the classroom (at all levels) together with the use of efficient teaching strategies. The task of selecting the resources and types of activities to carry out in the classroom, the commitment to a dynamic and experiential teaching strategy able to motivate children and teenagers, and making the contents to be taught interesting, attractive, and easy to understand should be a priority and should not depend on each teacher [42]. Choosing what and how to teach is equally important. In other words, the point of view from which the issue of floods and climate change is taught should be chosen correctly, as using excessive extremism or catastrophism is not conducive to learning [42]. Therefore, Cuello [26] adds that it is necessary to use new resources for the work in the classroom, going beyond the simplified models that are proposed in the textbooks. The huge quantity and diversity of information gathered, with its filters, biases, and conflicts of interest, offer great educational opportunities for teaching students about a more complex, integrated, and sustainable concept of rivers, their relationships with towns, and flooding events. In this way, the level of knowledge about these risks at an earlier age would increase. According to Morote [28], this is necessary because, in this way, the benefits are twofold: first, overall vulnerability would be reduced; and second, the capacity of the resilience of society would be reinforced. The importance of any educational activity resides in both aspects.

\section{Conclusions}

This study carried out a first analysis of the perception that future Primary Education teachers have of the risk of flooding. The starting hypotheses (first and third) were fulfilled. The majority of participants did not receive training on this subject during their school years. The perception that they have of the risk of flooding is that it has worsened in recent years, particularly due to climate change.

The small percentage of students ( $21.3 \%$ of the sample) who received information about natural risks during their school years showed that one of the main conclusions derived from this study is that increasing the knowledge of this subject among the youngest students should be a priority in schools. This statement was marked, in addition, because they value the factor "education" very little, even less than those who did not receive it. Therefore, teachers have the responsibility of transmitting this knowledge to their students and taking on the challenge that this subject represents, as it is one of the principal socio-environmental problems of the twenty-first century.

A second statement is that the lack of knowledge is accentuated by the origin of the sources from which the information is obtained (mainly the Internet), as indicated by certain studies [13], and the little relevance given to the education factor by future teachers. This is highly important, as it indicates the limited interest shown by these respondents. Therefore, this result is a cause for concern, as well as a contradiction taking into account that it will be these individuals who must train the youngest cohorts in the future.

Keeping in mind that sustainable development goals can be implemented thanks to the involvement of local communities in each region, social awareness and involvement are of meaningful value. In this research, a significant gap in the education of young teachers was identified, which may prove to be a valuable clue to solving the problem, i.e., creating appropriate curricula for this group. Educational programs should consider a holistic approach to environmental problems with an emphasis on the cause-effect nature of natural processes. Considering floods as an isolated phenomenon with a high risk and excluded from the broader context will not bring the expected results. For this reason, the teaching 
should be based on the water cycle. Similarly, understanding of the processes and relationships with human activities must be considered as basic knowledge. Based on proper basic knowledge, universal access to knowledge enables the implementation of life-long learning, and to this, awareness-raising and reliable education are crucial.

Moreover, it is necessary to establish and implement comprehensive educational programs for teachers. For example, for training and current teachers, it would be useful to give training courses about natural hazards and climate change by experts (i.e., from the university). These courses should aim at supplying resources and activities to complete in the classroom and scientific documents with data about these phenomena (trends, extreme events, etc.). With these resources, teachers would not use and rely on textbooks so much, as they are frequently characterized by stereotypes and mistakes [43]. For example, in the United Kingdom, specialist teachers on climate change have recently been incorporated into the Primary and Secondary Education centers, as this is one of the educational priorities. The United Kingdom became the first country in the world to have teachers accredited by the United Nations to teach courses and lessons on this phenomenon [44]. Furthermore, for teacher training, on the level of Primary Education, it would be necessary to consider seminars and subjects on these phenomena.

A future line of research derived from this study would be to promote and stress the importance of addressing these subjects from the discipline of Social Sciences and, more specifically, Geography. This science should figure more prominently in teacher training programs in order to increase teachers' knowledge regarding the interpretation of the geographical space and how the features of the physical environment, but also the occupation of the territory, influence the risk of flooding. Other future research challenges will be to determine the activities and resources that the respondents propose to teach this subject in the classroom. This would help to ensure that the same type of teaching that they received in their schooling is not repeated. Finally, it is worth highlighting that it is necessary to establish a risk culture with an awareness of the different hazards and vulnerability elements. To do this, from the education perspective, there will be an enormous challenge of raising awareness among the youngest students, which, through environmental education, would give rise to the creation of a society more resilient to floods and the future scenarios of climate change.

Author Contributions: Conceptualization, methodology, formal review, and investigation, Á.-F.M. and M.H. All authors have read and agreed to the published version of the manuscript.

Funding: The results presented in this article are part of the research project "Social representations of school content in the development of teaching competencies" funded by the Spanish MINECO under grant number PGC2018-094491-B-C32.

Conflicts of Interest: The authors declare no conflict of interest.

\section{References}

1. Pérez, A.; Gil, S.; Olcina, J. Housing bubbles and the increase of flood exposoure. Failures in flood risk management on the Spanish south-eastern coast (1975-2013). J. Flood Risk Manag. 2015, 11, 302-311. [CrossRef]

2. Centre for Research on the Epidemiology of Disasters (CRED). Economic Losses, Poverty \& Disasters (1998-2017). 2019. Available online: https://www.emdat.be/ (accessed on 11 April 2020).

3. European Environment Agency. Climate Change, Impacts and Vulnerability in Europe 2016. An Indicator-Based Report. 2017. Available online: https://www.eea.europa.eu/publications/climatechange-impacts-and-vulnerability-2016 (accessed on 29 July 2019).

4. Intergovernmental Panel on Climate Change (IPCC). Special Report Global Warming of $1.5^{\circ}$ C. 2018. Available online: https://www.ipcc.ch/report/sr15/ (accessed on 9 November 2019).

5. Centros de Estudios y Experimentación de Obras Públicas (CEDEX). Evaluación del Impacto del Cambio Climático en los Recursos Hídricos y Sequías en España. Centro de Estudios Hidrográficos; Ministerio de Fomento y Ministerio de Medio Ambiente: Madrid, Spain, 2017.

6. ESPON. 2008. Available online: https://www.espon.eu/ (accessed on 10 May 2020). 
7. Join Research Center. Atlas of the Human Planet 2017. Global Exposure to Natural Hazards. European Commission; DG Join Research Center: Ispra, Italy, 2017.

8. Olcina, J. Verdades y mentiras sobre el riesgo de inundaciones en el litoral mediterráneo: Balance de medio siglo. In Jornada sobre Fenómenos Meteorológicos Extremos en el Mediterráneo; AEMET: Valencia, Spain, 11 December 2018.

9. Olcina, J.; Saurí, D.; Hernández, M.; Ribas, A. Flood policy in Spain: A review for the period 1983-2013. Disaster Prev. Manag. Int. J. 2016, 25, 41-58. [CrossRef]

10. Plan de Acción Territorial sobre Prevención del Riesgo de Inundación en la Comunitat Valenciana (PATRICOVA). 2015. Available online: http://www.habitatge.gva.es/es/web/planificacion-territorialeinfraestructura-verde/patricova-docs (accessed on 20 April 2020).

11. Parker, D.J. Floodplain development policy in England and Wales. Appl. Geogr. 1995, 15, 341-363. [CrossRef]

12. Perles, M.J.; Sortino, J.F.; Cantarero, F. Cartografía de la vulnerabilidad del territorio frente al riesgo de inundación. Propuesta adaptada a la Directiva europea de inundaciones y normativas derivadas. Bol. Asoc. Geógr. Esp. 2017, 75, 341-372.

13. Morote, A.F. La enseñanza del cambio climático en la Educación Primaria. Exploración a partir de las representaciones sociales del futuro profesorado y los manuales escolares de Ciencias Sociales. ENSAYOS Rev. Fac. Educ. Albacete 2019, 34, 213-228.

14. Souto, X.M. La geografía escolar: Deseos institucionales y vivencias de aula. Bol. Asoc. Geógr. Esp. 2018, 79, 1-31. [CrossRef]

15. Morote, A.F. Percepción de los futuros maestros de Primaria sobre el riesgo de inundación. La Geografía como herramienta para lograr una sociedad más resiliente al cambio climático. Papeles Geogr. 2019, 65, 67-88. [CrossRef]

16. Barratt, R.; Hacking, E. Changing my locality: Conceptions of the future. Teach. Geogr. 2000, $25,17-21$.

17. Lutz, T. Toward a new conceptual framework for teaching about flood risk in introductory geoscience courses. J. Geosci. Educ. 2001, 59, 5-12. [CrossRef]

18. McWhirter, N.; Shealy, T. Case-based flipped classroom approach to teach sustainable infrastructure and decision-making. Int. J. Constr. Educ. Res. 2018, 16, 1-21. [CrossRef]

19. McEwen, L.; Stokes, A.; Crowley, K.; Roberts, C. Using role-play for expert science communication with professional stakeholders in flood risk management. J. Geogr. High. Educ. 2014, 38, 277-300. [CrossRef]

20. Lechowicz, M.; Nowacki, T. School education as an element of natural disaster risk reduction. Prace Stud. Geogr. 2014, 55, 85-95.

21. Bricelj, M. Kranjska stena-An example of good school practice. Geogr. Soli 2013, 22, 51-56.

22. Kovacs, A.; Ştefănie, H.; Botezan, C.; Crăciun, I.; Ozunu, A. Assesment of natural hazards in european countries with impact on young people. In Proceedings of the 17th International Multidisciplinary Scientific Geoconference, Surveying Geology and Mining Ecology Management, SGEM 2017, Albena, Bulgaria, 29 June-5 July 2017; Volume 17, pp. 73-80.

23. Ahmad, S.; Numan, S.M. Potentiality of disaster management education through open and distance learning system in Bangladesh Open University. Turk. Online J. Distance Educ. 2015, 16, 249-260. [CrossRef]

24. Díez, A. Buscando riadas en los árboles: Dendrogeomorfología. Enseñ. Cienc. Tierra 2015, 23, $272-285$.

25. Garzón, G.; Ortega, J.A.; Garrote, J. Las avenidas torrenciales en cauces efímeros: Ramblas y abanicos aluviales. Enseñ. Cienc. Tierra 2009, 17, 264-276.

26. Cuello, A. Las Inundaciones del invierno 2009-2010 en la prensa, un recurso educativo para las ciencias sociales. Rev. Investig. Didáct. Cienc. Soc. 2013, 2, 70-87.

27. Ollero, A. Crecidas e inundaciones como riesgo hidrológico. Un planteamiento didáctico. Lurralde 1997, 20, 261-283.

28. Morote, A.F. El Parque Inundable La Marjal de Alicante (España) como propuesta didáctica para la interpretación de los espacios de riesgo de inundación. Didáct. Geogr. 2017, 18, 211-230.

29. Morote, A.F.; Pérez, A. La comprensión del riesgo de inundación a través del trabajo de campo: Una experiencia didáctica en San Vicente del Raspeig (Alicante). Vegueta Anu. Fac. Geogr. Hist. 2019, 19, 609-631.

30. Souto, X.M.; Morote, A.F.; García, D. Crisis y riesgos naturales en la educación social. El caso del riesgo de inundación en Educación Primaria. In Crisis y Espacios de Oportunidad. Retos para la Geografía; AGE and University of Valencia: Valencia, Spain, 2019; pp. 171-185.

31. Woodhouse, S. Exploring the future. Prim. Geogr. 2007, 64, 38-39. 
32. Spear, P. Get in the picture about climate change. Prim. Geogr. 2018, 96, 26-27.

33. Calvo, F. Sociedades y Territorios en Riesgo; Ediciones del Serbal: Barcelona, Spain, 2001.

34. Universidad de Valencia. Anuario Estadístico. 2020. Available online: https://webges.uv.es/MS10/servlet/ mstrWeb? evt=3010\&Server=MSTRATEGY\&Project=RECULL\& (accessed on 21 March 2020).

35. Morote, A.F.; Souto, X.M. Educar para convivir con el riesgo de inundación. Rev. Estud. Geogr. 2020, 81, 1-14. [CrossRef]

36. Abbot, B.W.K.; Bishop, J.P.; Zarnetske, C.; Minaudo, F.S.; Chapin, S.; Krause, D.M.; Hannah, L.; Conner, D.; Ellison, S.E.; Godsey, S.; et al. Human domination of the global water cycle absent from depictions and perceptions. Nat. Geosci. 2019, 12,1-11. [CrossRef]

37. Ramiro, E. Per què s'inunda la Ribera. BALMA Didàct. Ciènc. Soc. Geogr. Hist. 1996, 3, 89-96.

38. Chevallard, Y. La Transposition Didactique du Savoir Savant au Savoir Enseigné; La Pensée Sauvage Éditions: Grenoble, France, 1991.

39. Arto, M. O cambio climático narrado por alumnos de educación secundaria: Análise de metáforas e iconas. AmbientalMENTE Sustentable 2009, 7, 115-125.

40. González, E.; Maldonado, A. ¿Qué piensan, dicen y hacen los jóvenes universitarios sobre el cambio climático? Un estudio de representaciones sociales. Educ. Rev. 2014, 3, 35-55. [CrossRef]

41. Morote, A.F.; Campo, B.A.; Colomer, J.C. La percepción del cambio climático en los futuros docentes de Educación Primaria. Una experiencia de conocimientos previos a partir de la enseñanza de las Ciencias Sociales. In Crisis y Espacios de Oportunidad. Retos para la Geografí; AGE and University of Valencia: Valencia, Spain, 2019; pp. 106-120.

42. Martínez, L.C.; Olcina, J. La enseñanza escolar del tiempo atmosférico y del clima en España: Currículo educativo y propuestas didácticas. An. Geogr. Univ. Complut. 2019, 39, 125-148. [CrossRef]

43. Morote, A.F. ¿Cómo se trata el tiempo atmosférico y el clima en la Educación Primaria? Una exploración a partir de los recursos y actividades de los manuales escolares de Ciencias Sociales. Espac. Tiempo Forma Ser. VI Geogr. 2020, 13, 119-144.

44. Ecoinventos. Reino Unido Incorpora a sus Colegios a Profesores Especialistas en el Cambio Climático. Ecoinventos. 2019. Available online: https://ecoinventos.com/reino-unido-incorpora-a-sus-colegios-aprofesores-especialistas-en-el-cambio-climatico/?fbclid=IwAR1bsdJD3MwOIFc0g4wYK9JRMZmVp3xPSeos9 U-57iWDI3JNWk0GAkCH1WI (accessed on 22 July 2020). 